\title{
Causal Analysis of the Uncontrolled Moderator in the HFEF Main Cell
}

Charles R. Posegate Bryan P. Croft

December 2012

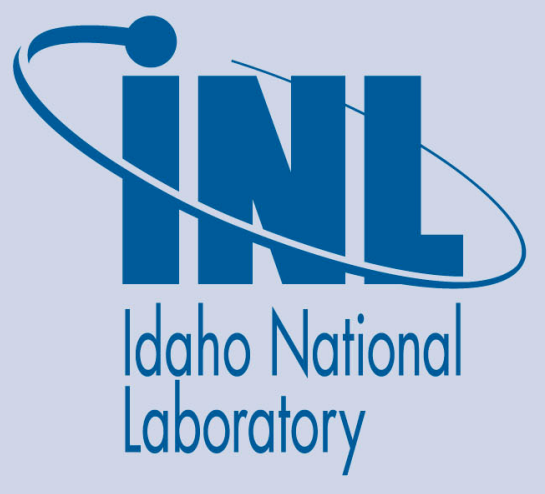

The INL is a U.S. Department of Energy National Laboratory operated by Battelle Energy Alliance 
INL/EXT-12-27982

\title{
Causal Analysis of the Uncontrolled Moderator in the HFEF Main Cell
}

\author{
Level 1 Cause Analysis \\ ORPS Number: NE-ID-BEA-HFEF-2012-0005 \\ ICAMS Number: IO-023440 \\ Event Occurred: November 6, 2012
}

Charles R. Posegate, BEA Cause Analyst

Bryan P. Croft, BEA Cause Analyst

Sean S. Cunningham, BEA Responsible Manager

December 2012

\author{
Idaho National Laboratory \\ Idaho Falls, Idaho 83415
}

http://www.inl.gov

Prepared for the U.S. Department of Energy Office of Nuclear Energy Under DOE Idaho Operations Office

Contract DE-AC07-05ID14517 


\section{DISCLAIMER}

This information was prepared as an account of work sponsored by an agency of the U.S. Government. Neither the U.S. Government nor any agency thereof, nor any of their employees, makes any warranty, expressed or implied, or assumes any legal liability or responsibility for the accuracy, completeness, or usefulness, of any information, apparatus, product, or process disclosed, or represents that its use would not infringe privately owned rights. References herein to any specific commercial product, process, or service by trade name, trade mark, manufacturer, or otherwise, does not necessarily constitute or imply its endorsement, recommendation, or favoring by the U.S. Government or any agency thereof. The views and opinions of authors expressed herein do not necessarily state or reflect those of the U.S. Government or any agency thereof. 
Causal Analysis of the Uncontrolled Moderator in the HFEF Main Cell

Level 1 Cause Analysis

ORPS Number: NE-ID--BEA-HFEF-2012-0005

INL/EXT-12-27982

Revision 0

December 2012
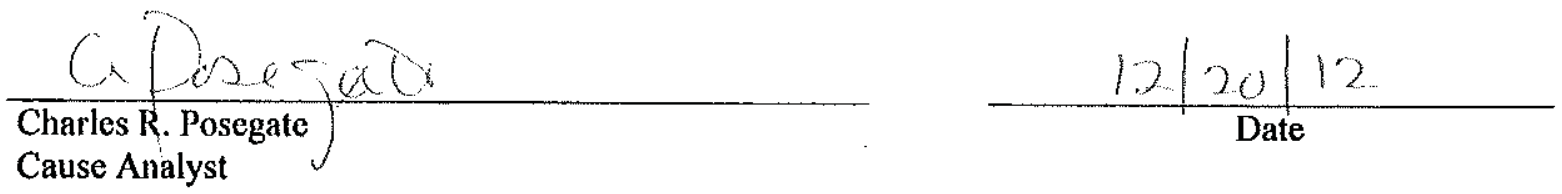

GRadate tor Bryan Goof PiC

Bryan P. Croft

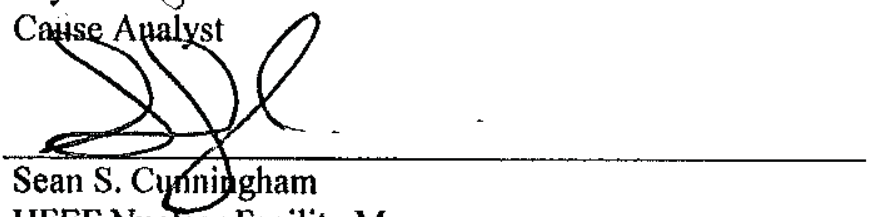

HFEF Nuclear Facility Manager

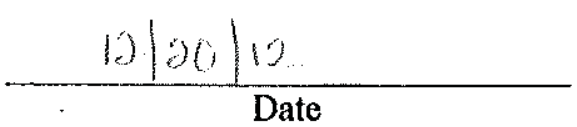

Approved by:

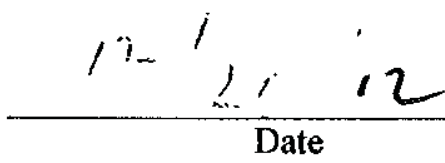

MFC Mission Support Director

Riley R Chase

Riley R. Chase

Deputy Laboratory Director,

Projects, Nuclear Support and Production

$12 / 20 / 12$

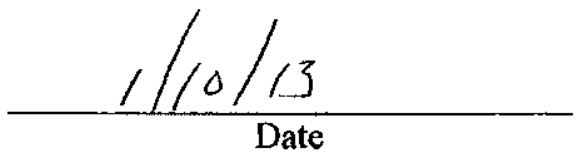




\begin{tabular}{|c|ll|}
\hline CAUSAL ANALYSIS OF THE & Identifier: & INL/EXT-12-27982 \\
$\begin{array}{c}\text { UNCONTROLLED MODERATOR IN THE } \\
\text { Revision: }\end{array}$ & 0 & \\
Effective Date: & $12 / 19 / 2012$ & Page: v of viii \\
\hline
\end{tabular}

\section{Executive Summary}

The Hot Fuel Examination Facility (HFEF) is a Hazard Category 2 nuclear facility, located at the Materials and Fuels Complex (MFC) at the Idaho National Laboratory (INL). The facility contains state of the art hot cells used for examination and characterization of irradiated materials, primarily in support of U. S. Department of Energy (DOE) programs. The Neutron Radiography Reactor (NRAD) facility, which is located within HFEF, contains a Training, Research, and Isotope, General Atomics (TRIGA) reactor that is operated as an irradiation source and provides for neutron radiography of both irradiated and un-irradiated specimens.

Fissionable material operations within HFEF are primarily associated with:

- Spent Fuel Treatment Project support

- Post irradiation exam of sample materials for various DOE projects

- Neutron radiography

- Work-for-others projects.

On 11/07/2012 while investigating the cause of defects in neutron radiography film at HFEF, oil was discovered near the elevator shaft located at the $4 \mathrm{M}$ location within the Main Cell. Subsequent investigation identified oil (untracked moderator) in several locations of the HFEF Main Cell. Initial analysis determined that oil leaking from a $1 \mathrm{M}$ shielding window had leaked past a compensatory containment system resulting in a thin layer of oil found in several locations on the main cell floor. The result of this condition is uncontrolled moderator in moderator controlled zones, which is a violation of Criticality Hazard Control Statements (CHCS) for HFEF.

A critique was held on November 7,2012 to determine the facts and extent of the situation and to categorize the event. Based on the extent of the leak, MFC Management determined that ORPS reporting criterion Group 3 Subgroup C (4) Significance Category 3 had been met. Though this was a violation of a criticality control, it was determined that the event did not create an unsafe condition. The thin layer of oil on the floor cannot easily mix with fissionable material.

A Causal Analysis Team was assigned to investigate the events that led up to the loss of moderator control in the HFEF Main Cell. The investigation focused on the leak from window $1 \mathrm{M}$, primarily on the controls established to contain the leak and any plans for fixing or repairing the window oil seal. The window is part of the HFEF Main Cell, located on the north side west corner of the cell.

The causes for this violation are the failures to adequately assess and implement controls for the leaking window and assess the impact of the leak which has resulted in a Potential Inadequacy of the Safety Analysis (PISA) for the HFEF. 


\begin{tabular}{|c|c|c|c|}
\hline $\begin{array}{l}\text { CAUSAL ANALYSIS OF THE } \\
\text { UNCONTROLLED MODERATOR IN THE } \\
\text { HFEF MAIN CELL }\end{array}$ & $\begin{array}{l}\text { Identifier: } \\
\text { Revision: } \\
\text { Effective Date: }\end{array}$ & $\begin{array}{l}\text { TNL/EXT-1 } \\
0 \\
12 / 19 / 2012\end{array}$ & Page: vi of viii \\
\hline
\end{tabular}

\section{CONTENTS}

ACRONYMS vii

DEFINITIONS viii

1. BACKGROUND... 1

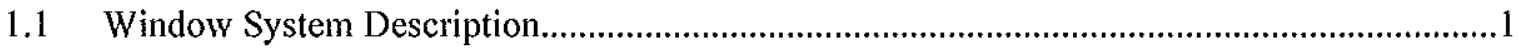

$1.2 \quad$ A-Slab Lead Sheet Packing Failure ..........................................................................

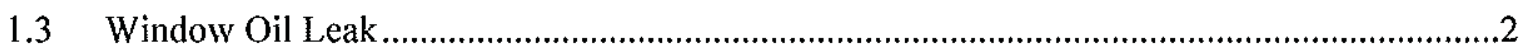

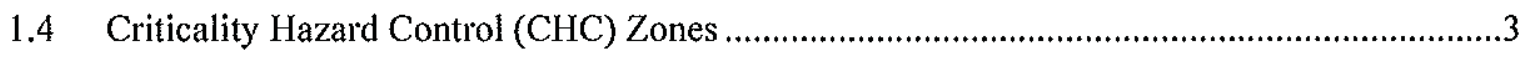

1.5 Problem Identification and Subsequent Actions .......................................................5

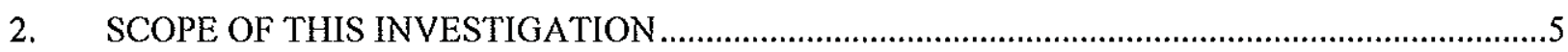

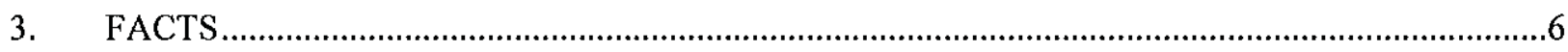

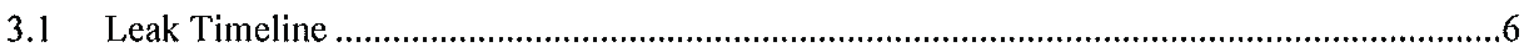

3.2 Discussion of the Evaluation and Mitigations of the Leaking Window .................................

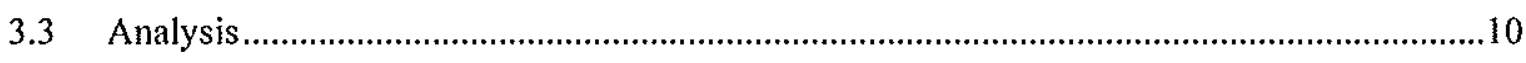

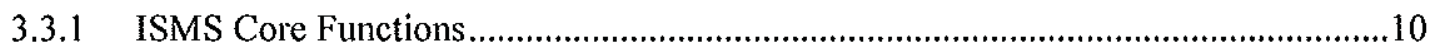

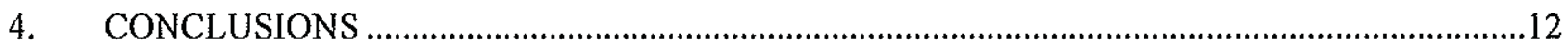

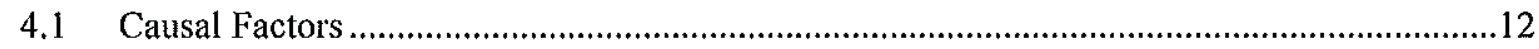

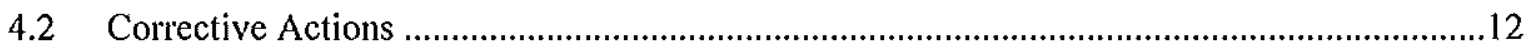

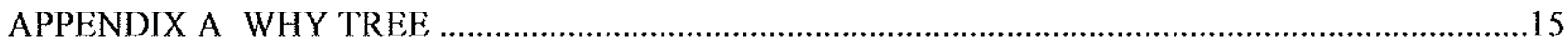

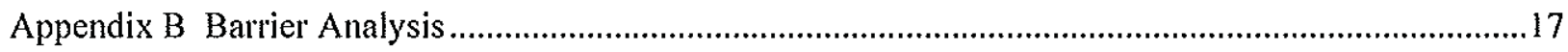

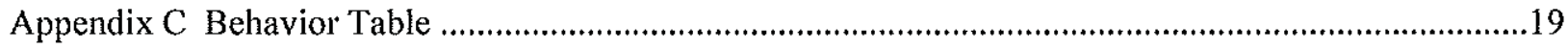

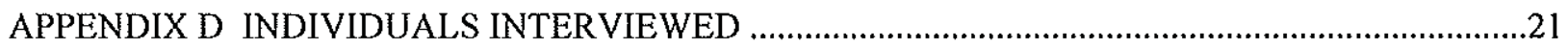

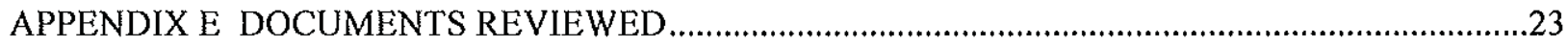




\begin{tabular}{|c|c|c|c|}
\hline $\begin{array}{l}\text { CAUSAL ANALYSIS OF THE } \\
\text { UNCONTROLLED MODERATOR IN THE } \\
\text { HFEF MAIN CELL }\end{array}$ & $\begin{array}{l}\text { Identifier: } \\
\text { Revision: } \\
\text { Effective Date: }\end{array}$ & $\begin{array}{l}\text { INL/EXT-1 } \\
0 \\
12 / 19 / 2012\end{array}$ & Page: vii of viii \\
\hline
\end{tabular}

\section{ACRONYMS}

\begin{tabular}{|c|c|}
\hline Admin & Administrative \\
\hline ALARA & As Low As Reasonably Achievable \\
\hline BEA & Battelle Energy Alliance \\
\hline $\mathrm{CHCS}$ & Criticality Hazard Control Statement \\
\hline $\mathrm{HCA}$ & High Contamination Area \\
\hline HFEF & Hot Fuel Examination Facility \\
\hline $\mathrm{h}$ & Hour \\
\hline IFM & Idaho Facilities Management \\
\hline INL & Idaho National Laboratory \\
\hline IPL & Integrated Priority List \\
\hline ISMS & Integrated Safety Management System \\
\hline LOW & Latent Organizational Weakness \\
\hline LTA & Less Than Adequate \\
\hline $\mathrm{MFC}$ & Materials and Fuels Complex \\
\hline NFM & Nuclear Facility Manager \\
\hline NRAD & Neutron Radiography Reactor \\
\hline NS\&T & Nuclear Science and Technology \\
\hline OMB & Office of Management and Budget \\
\hline Op & Operator \\
\hline PI & Principal Investigator \\
\hline PIE & Post-Irradiation Examination \\
\hline PISA & Potential Inadequacy of the Safety Analysis \\
\hline $\mathrm{SS}$ & Shift Supervisor \\
\hline USQ & Unreviewed Safety Question \\
\hline USQ-RD & Unreviewed Safety Question-Reasonability Determination \\
\hline w.g. & water gauge \\
\hline
\end{tabular}




\begin{tabular}{|c|c|c|c|}
\hline $\begin{array}{l}\text { CAUSAL ANALYSIS OF THE } \\
\text { UNCONTROLLED MODERATOR IN THE } \\
\text { HFEF MAIN CELL }\end{array}$ & $\begin{array}{l}\text { Identifier: } \\
\text { Revision: } \\
\text { Effective Date: }\end{array}$ & $\begin{array}{l}\text { INL/EXT-1 } \\
0 \\
12 / 19 / 2012\end{array}$ & Page: viii of viii \\
\hline
\end{tabular}

\section{DEFINITIONS}

$U 5 E$. The mass of fissionable nuclides calculated as a ${ }^{235} \mathrm{U}$ equivalent mass.

$$
\mathrm{U} E \mathrm{E}={ }^{235} \mathrm{U}+\mathbf{4 x}\left({ }^{233} \mathrm{U}+\mathrm{Pu}+\mathrm{Np}+\mathrm{Am}+\mathbf{C m}+\mathbf{C f}\right)
$$

NOTE: The ${ }^{235} U$ in depleted or natural wranium does not contribute to U5E values. 


\begin{tabular}{|c|c|c|c|}
\hline $\begin{array}{c}\text { CAUSAL ANALYSIS OF THE } \\
\text { UNCONTROLLED MODERATOR IN THE } \\
\text { HFEF MAIN CELL }\end{array}$ & $\begin{array}{l}\text { Identifier: } \\
\text { Revision: } \\
\text { Effective Date: }\end{array}$ & $\begin{array}{l}\text { INL/EXT-12-27982 } \\
0 \\
12 / 19 / 2012\end{array}$ & Page: 1 of 23 \\
\hline
\end{tabular}

\section{Causal Analysis of the Uncontrolled Moderator in the HFEF Main Cell}

\section{BACKGROUND}

The Hot Fuel Examination Facility (HFEF) is a Hazard Category 2 nuclear facility, located at the Materials and Fuels Complex (MFC) at the Idaho National Laboratory (INL), in which Post-Irradiation Examination (PIE) processes are conducted within a large, inert hot cell using remote equipment via oilfilled shielded windows. The Main Cell is divided up into different zones so as to control the amount of fissile material and moderator allowed within each zone. Each zone is classified as either a "moderator" unlimited" zone where the fissile mass content must remain below $350 \mathrm{~g}$ USE or as a "moderator limited" zone where the fissile mass content can extend into the range of $10,000 \mathrm{~g}$ U5E with no moderator" allowed.

\subsection{Window System Description}

The HFEF IM window was supplied by H.V. Harty Co. in 1972. The window system consists of two major components: the window tank unit and the A-slab.

The window tank unit contains five slabs of shielding glass (labeled B through F) mounted in a steel tank. The space between the slabs is filled with a high grade mineral oil to improve optical clarity and coupling of the glass. An oil expansion tank is provided above the tank unit. The expansion tank is purged with argon gas at $10 \mathrm{in}$. w.g. to minimize absorption of contaminants in the oil which can cause degradation of the glass surfaces.

The window tank unit assembly is inserted from the cold side (operating corridor) and is bolted to the out-of-cell side of the liner flange. The liner flange is structurally and seal welded to the cell liner to form the cell confinement boundary. The mechanical joint between the window tank unit and liner flange has a primary gas seal which is purged with argon gas to minimize the ingress of oxygen into the cell.

The A-slab is a hinged protective cover plate installed from the cell side and bolted to the hot side of the liner flange. The space between the A-slab and window tank unit is purged with argon gas. The mechanical joint between the A-slab and liner flange has a dust seal which allows leakage of the purge gas between the A-slab and window tank unit into the cell. Provision for installation of a secondary gas seal allows the A-slab to be the confinement boundary to allow removal of the tank unit for corrective maintenance. The A-slab can be remotely removed by removing the bolts between the A-slab window frame and liner flange. The $A$-slab swings open into the cell where the overhead manipulator (EMM) is used to install a lifting bail. The in-cell crane then lifts the A-slab from the hinge pins for transfer out of the cell. Installation is performed in the reverse order. If necessary, jacking screws are provided to break loose the seal between the A-slab and the liner flange.

\subsection{A-Slab Lead Sheet Packing Failure}

The A-slab window is cushioned with lead sheets between the glass and steel frame. The free space around the glass is packed with lead wool to hold the glass in place. The piece of lead sheeting on the top horizontal surface of the glass has fallen out of position and is currently suspended by the west corner of the window frame. Based on discussions with engineering, the loss of the lead sheeting may indicate that the A-slab glass has shifted in the window frame. Shifting in the A-slab may be caused by inadvertent contact from in-cell operations or "walking" of the glass in the frame caused by thermal effects. 


\section{CAUSAL ANALYSIS OF THE UNCONTROLLED MODERATOR IN THE HFEF MAIN CELL}

Identifier: $\quad$ TNL/EXT-12-27982

Revision: $\quad 0$

Effective Date: 12/19/2012 Page: 2 of 23

\subsection{Window Oil Leak}

For the oil to leak into the cell the window oil must leak past an oil seal and a dust seal (depicted by the red line in the figure below). First, the hot side of the tank unit is sealed between the B-slab and the window tank structure. This seal is an elastomeric flat gasket which is compressed by the B-slab mounting bolts. The second seal is the dust seal between the A-slab and the liner flange. This seal is not intended to be a leak-tight seal. The current leak rate is estimated at $8 \mathrm{fl}$. oz. per day. These seals are approximately 40 years old.

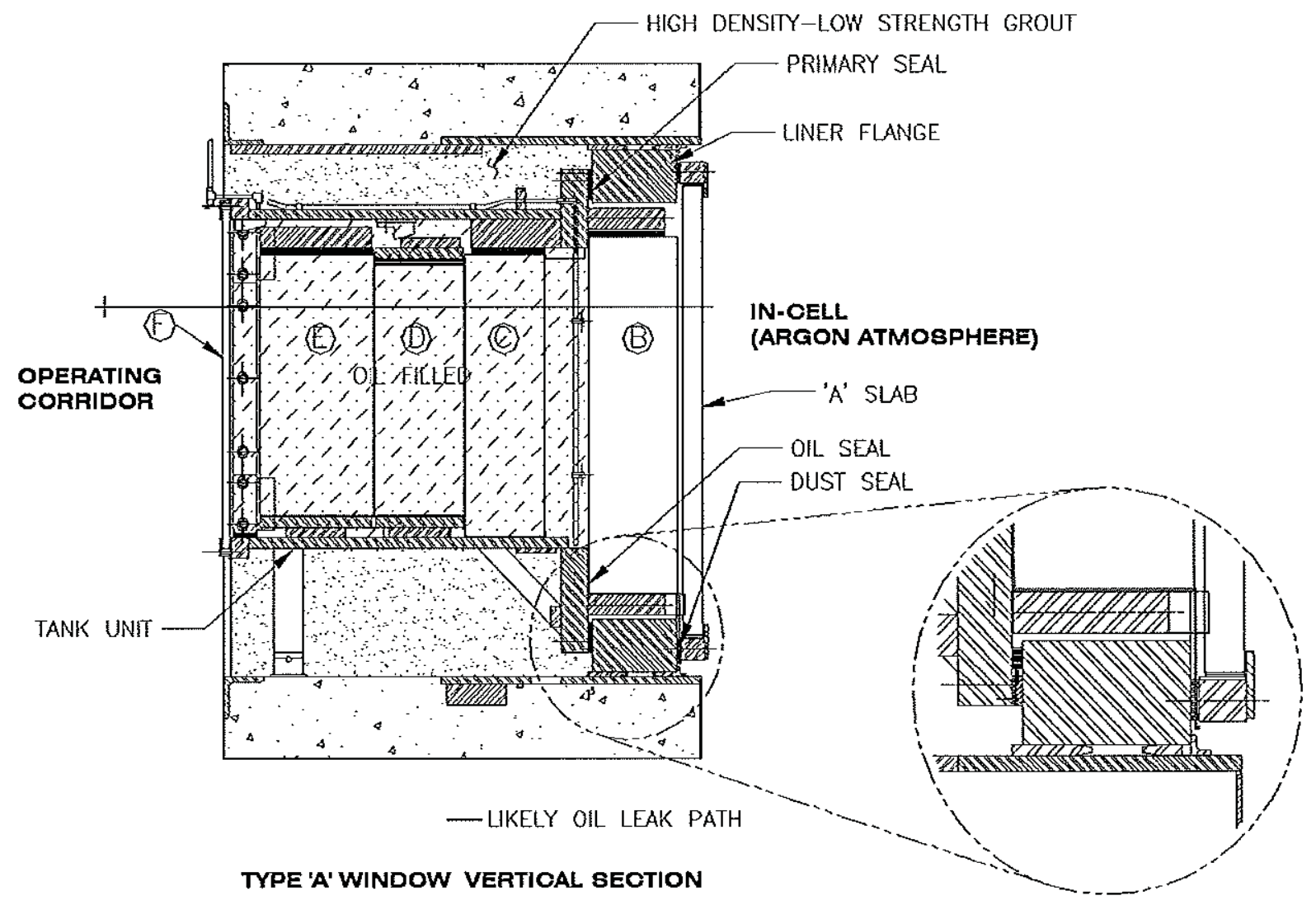

Figure 1. Type-A window vertical section. 


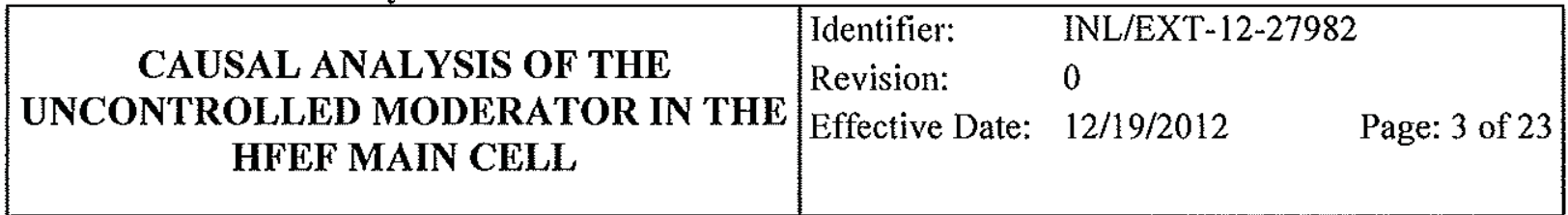

\subsection{Criticality Hazard Control ( $\mathrm{CHC}$ ) Zones}

The diagram below provides a view of the zones within the Main Cell with the table describing the general work activities within each zone.

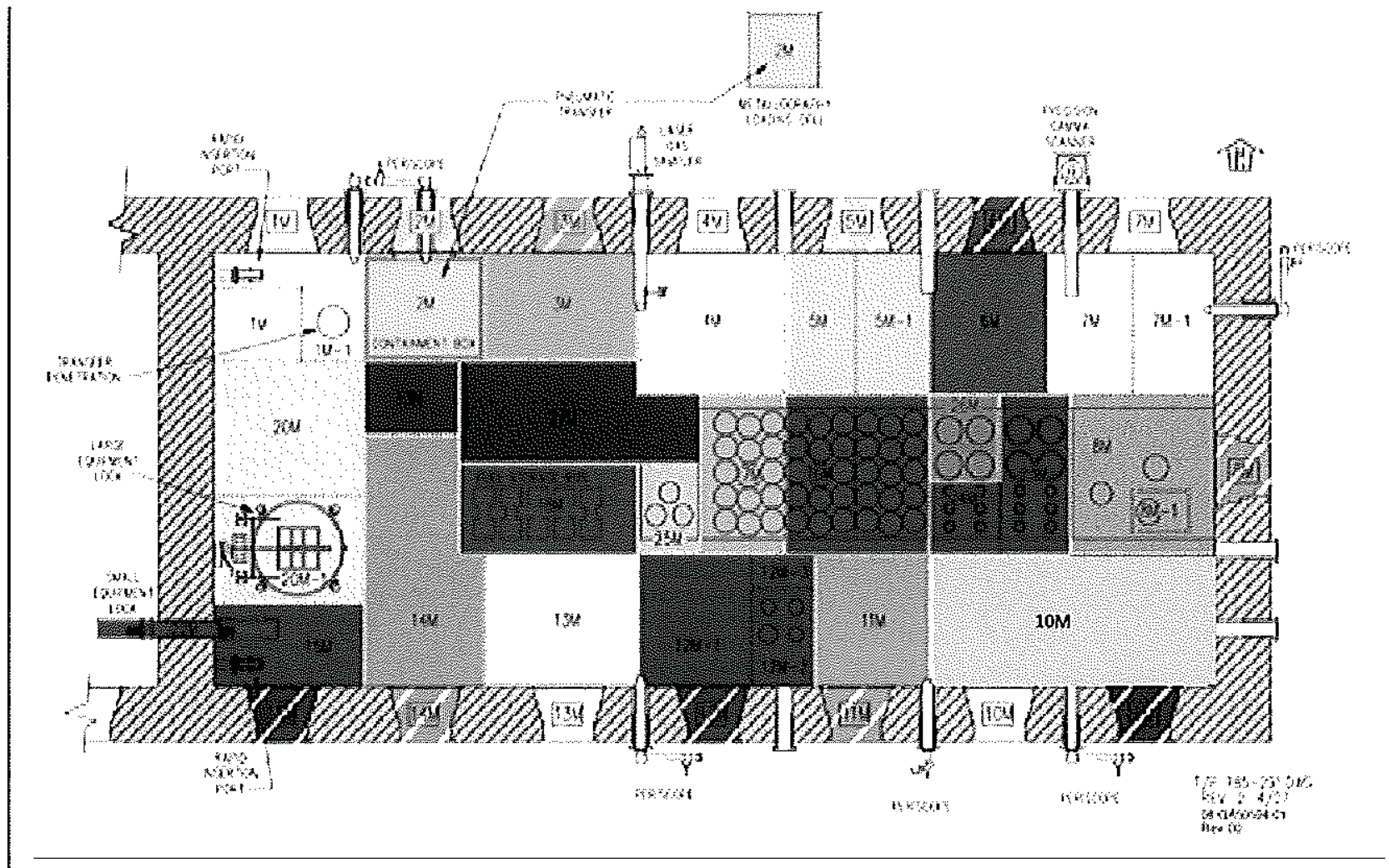

Figure 2. Main cell zone layout. 
Idaho National Laboratory

\begin{tabular}{|c|c|c|c|}
\hline $\begin{array}{c}\text { CAUSAL ANALYSIS OF THE } \\
\text { UNCONTROLLED MODERATOR IN THE } \\
\text { HFEF MAIN CELL }\end{array}$ & $\begin{array}{l}\text { Identifier: } \\
\text { Revision: } \\
\text { Effective Date: }\end{array}$ & $\begin{array}{l}\text { INL/EXT-12-27982 } \\
0 \\
12 / 19 / 2012\end{array}$ & Page: 4 of 23 \\
\hline
\end{tabular}

Table 1: Main Cell Zones and General Work Activities

\begin{tabular}{|c|c|c|c|}
\hline $\begin{array}{l}\mathrm{CHC} \\
\text { Zone }\end{array}$ & Designation & CHC Zone & Designation \\
\hline $1 \mathrm{M}$ & $\begin{array}{l}\text { Storage and Work Area (including } \\
\text { adjacent wall) }\end{array}$ & & $\begin{array}{l}\text { Waste can pits; waste disposal } \\
\text { storage area }\end{array}$ \\
\hline $1 \mathrm{M}-1$ & $\begin{array}{l}\text { Transfer Zone - cask tunnel } \\
\text { penetration }\end{array}$ & $13 \mathrm{M}$ & $\begin{array}{l}\text { Storage and Work Area; } \\
\text { V-mixer }\end{array}$ \\
\hline $2 \mathrm{M}$ & $\begin{array}{l}\text { Containment Box (includes } \\
\text { Metallography Loading Cell in Room } \\
\text { 123) }\end{array}$ & $14 \mathrm{M}$ & $\begin{array}{l}\text { Storage and Work Area; } \\
\text { crusher; grinder classifier }\end{array}$ \\
\hline $3 \mathrm{M}$ & Storage and Work Area & & $\begin{array}{l}\text { Storage and Work Area; } \\
\text { pneumatic transfer station }\end{array}$ \\
\hline $4 \mathrm{M}$ & $\begin{array}{l}\text { Element transfer station; NRAD pit with } \\
\text { elevator; Gas Assay Sample and } \\
\text { Recharge (GASR) system }\end{array}$ & & Cladding hull storage area \\
\hline $5 \mathrm{M}$ & $\begin{array}{l}\text { Examination station; profilometer; bow } \\
\text { and length gauge }\end{array}$ & $17 \mathrm{M}$ & $\begin{array}{l}\text { Fuel element, cladding hull and } \\
\text { waste storage area }\end{array}$ \\
\hline $5 M-1$ & Storage and Work Area & 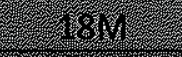 & Storage pits \\
\hline 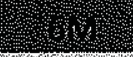 & FACS furnace & & EBR-II fuel bottle storage area \\
\hline $7 \mathrm{M}$ & $\begin{array}{l}\text { Examination station; precision gamma } \\
\text { scanner }\end{array}$ & $20 \mathrm{M}$ & Storage and Work Area \\
\hline $7 \mathrm{M}-1$ & $\begin{array}{l}\text { Examination station; visual examination } \\
\text { machine }\end{array}$ & $20 \mathrm{M}-1$ & $\begin{array}{l}\text { Transfer Zone - large } \\
\text { equipment lock, vacuum } \\
\text { chamber and transfer tunnel }\end{array}$ \\
\hline $8 \mathrm{M}$ & Metal waste casting & 政 & $\begin{array}{l}\text { Transfer Zone - small } \\
\text { equipment lock to Decon Cell }\end{array}$ \\
\hline $8 \mathrm{ML}_{1}$ & Metal waste ingot storage & & Storage Area \\
\hline & & & Storage Area \\
\hline $10 \mathrm{M}$ & Storage and Work Area & $25 \mathrm{M}$ & Storage Area \\
\hline$\left(1,4 M^{2}\right.$ & $\begin{array}{l}\text { Storage and Work Area; milling } \\
\text { machine station }\end{array}$ & & FFTF fuel storage \\
\hline 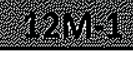 & Storage and Work Area; cut-off saw & & Storage Area \\
\hline
\end{tabular}




\begin{tabular}{|c|c|c|c|}
\hline $\begin{array}{l}\text { CAUSAL ANALYSIS OF THE } \\
\text { UNCONTROLLED MODERATOR IN THE } \\
\text { HFEF MAIN CELL }\end{array}$ & $\begin{array}{l}\text { Identifier: } \\
\text { Revision: } \\
\text { Effective Date: }\end{array}$ & $\begin{array}{l}\text { INL/EXT-12-27982 } \\
0 \\
12 / 19 / 2012\end{array}$ & Page: 5 of 23 \\
\hline
\end{tabular}

\subsection{Problem Identification and Subsequent Actions}

On November 1, 2012, oil leaking from main cell window IM was discovered on the sub-floor area of the HFEF main cell near the elevator tube at window 4M. Further investigation identified oil on the main cell floor in moderator limited zones.

On 11/07/2012 while investigating the cause of defects in neutron radiography film at HFEF, oil was discovered near the elevator shaft located at the $4 \mathrm{M}$ location within the Main Cell. Subsequent investigation identified oil (untracked moderator) in several locations of the HFEF Main Cell. Initial analysis determined that oil leaking from a shielding window had leaked past a compensatory containment system (i.e. the catch tray) resulting in a thin layer of oil found in several locations on the main cell floor. The result of this condition was uncontrolled moderator in moderator controlled zones, which was a violation of criticality control procedures (HFEF-OI-1020) for HFEF.

On $11 / 07 / 2012$ at 1700 hours, MFC Management determined that ORPS reporting criterion Group 3 Subgroup C (4) Significance Category 3 had been met and DOE-ID was notified of the event. Though this was a violation of a criticality control, it was determined that the event did not create an unsafe condition. The thin layer of oil on the floor cannot easily mix with fissionable material.

On 11/26/12 an Unreviewed Safety Question - Reasonability Determination (USQ-RD) was completed based on the information provided about the leak and the Determination was positive. Safe condition controls were established by the HFEF Nuclear Facility Manager (NFM). Based on the results of the Determination, the PISA process commenced in which on 12/03/12 a PISA was declared.

The basis for the PISA is the loss of control of window oil results in untracked moderator within some main cell criticality zones that may exceed the criticality safety limits for moderated-limited CHC Zones.

\section{SCOPE OF THIS INVESTIGATION}

This investigation is limited to analyze and identify the underlying cause to the $1 \mathrm{M}$ oil leak and loss of control of moderator material in the HFEF main cell as reported on November 7, 2012. The intent of this investigation is to establish the facts and determine causes that contributed to the event. Corrective actions have been developed, and are included in this report, to address the causes of this event as well as other issues identified during the course of this investigation. This issue and its corrective actions will be tracked in ICAMS issue number IO-023440 under source document SD-007138. 


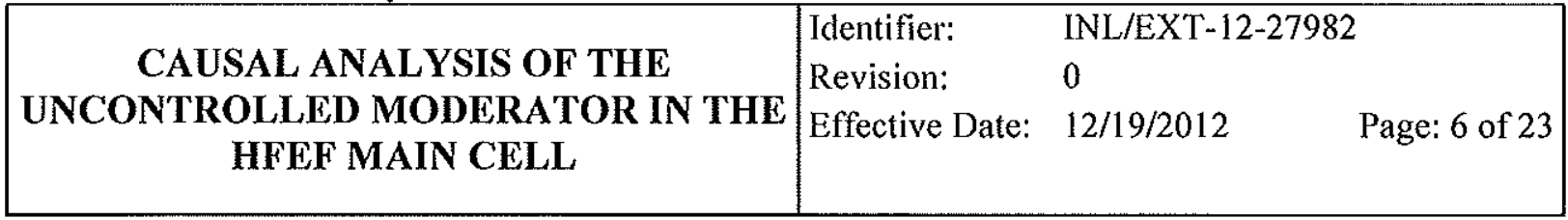

\section{FACTS}

\subsection{Leak Timeline}

\begin{tabular}{|c|c|}
\hline Date & Action/Activity \\
\hline $2007 / 2008$ & $\begin{array}{l}\text { In } 2007 / 2008 \text { timeframe, a facility walk through conducted by Operators and } \\
\text { the Nuclear Facility Manager (NFM) identified a small amount of oil at the } \\
1 \mathrm{M} \text { Zone. Cleanup efforts at Zone } 1 \mathrm{M} \text { were initiated and included the use of } \\
\text { chem wipes to collect the small amount of oil in the Zone. Logs were initiated } \\
\text { to capture the amount of oil being added to the Window at Zone } 1 \mathrm{M} \text {. At this } \\
\text { time there were no noticeable puddles developing due to the leak. } \\
\text { Engineering was tasked to evaluate and determine methods to fix the leak of } \\
\text { the } 1 \mathrm{M} \text { Window. A cost analysis on repairing the window was performed and } \\
\text { the result was an evaluated cost of } \$ 1.5 \text { million. The issue was documented in } \\
\text { the Risk Register and added to the Integrated Priority List (IPL); a priority list } \\
\text { to fund high concern matters. At this time, there was no evidence indicating } \\
\text { that oil had migrated out of the } 1 \mathrm{M} \text { Zone. At this time, the oil was evaluated } \\
\text { and not considered moderator by CSO. }\end{array}$ \\
\hline 2009/2010: & $\begin{array}{l}\text { In } 2009 / 2010 \text { timeframe, discussions on methods to capture oil from the } \\
1 \mathrm{M} \text { Window were started. After evaluation, a collection tray unit was } \\
\text { considered a possible method to collect oil at Window } 1 \mathrm{M} \text {. Plans to build the } \\
\text { collection tray were in development. }\end{array}$ \\
\hline Fall of 2010 & $\begin{array}{l}\text { Material cleanup continued and tracking of oil additions to the Window were } \\
\text { being conducted. A noticeable increase in oil being added to the } 1 \mathrm{M} \text { Window } \\
\text { was identified. At this time, oil was observed in an additional Zone (20M) } \\
\text { and a determination made that it had migrated from the Zone } 1 \mathrm{M} \text { Window. } \\
\text { Plastic was laid down in Zone } 20 \mathrm{M} \text { to prevent oil from getting to equipment } \\
\text { positioned on the floor. At this same time, another evaluation was performed } \\
\text { to determine the cost associated with the leak repair of Window } 1 \mathrm{M} \text {. The cost } \\
\text { was estimated to be approximately } \$ 4.5 \text { million. }\end{array}$ \\
\hline 2010 & $\begin{array}{l}\text { Neutron Radiography Reactor Facility (NRAD) personnel placed a camera in } \\
\text { the elevator shaft and no oil was identified in the bottom of the shaft. }\end{array}$ \\
\hline 2011: & $\begin{array}{l}\text { In Jan. MFC performed a stand down to evaluate and revise RWP's. } \\
\text { In April as RWP's were approved, resumption of work began. }\end{array}$ \\
\hline
\end{tabular}




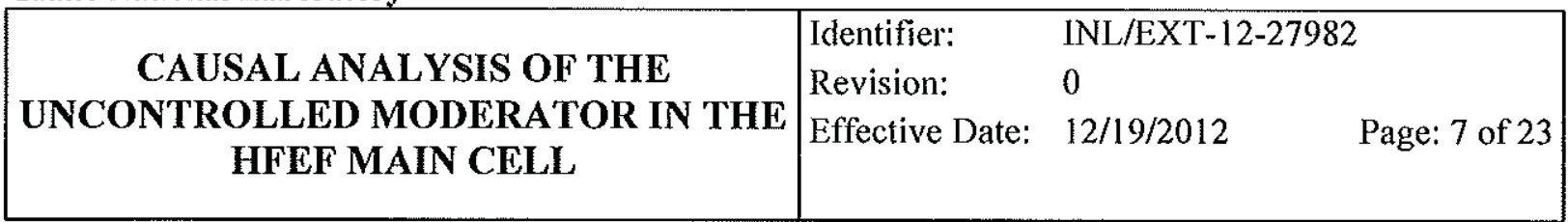

\begin{tabular}{|c|c|}
\hline Date & Action/Activity \\
\hline May 24, 2011 & $\begin{array}{l}\text { In May, } 2011 \text {, Criticality Safety Engineering analyzed the effects of the catch } \\
\text { tray being placed in cell and issued rev. } 8 \text { of the CHCS to allow the use of the } \\
\text { catch tray. The changes included the removal of rule M-1 (Rule } M-I \text {. It } \\
\text { states: If a moderating material's manner of use clearly precludes it from } \\
\text { acting as a moderator, the HFEF CSO may declare the material "not } \\
\text { moderator." This declaration shall be documented. Material declared "not } \\
\text { moderator" is not counted against moderator mass limits.) and added this } \\
\text { control: (Zone } 1 \mathrm{M}-1 \text { is allowed one (1) maximum 5-liter container of } \\
\text { moderator, intended for the collection of oil leaking from Window } 1 \mathrm{M} \text {. The } \\
5 \text {-liter volume is less than the subcritical limit for fully reflected, optimally } \\
\text { moderated solution of fully enriched } 235 \mathrm{U} \text { (LA-12808) and does not present } \\
\text { a critically safety concern. This } 5 \text {-liter container of moderator may be in Zone } \\
\text { 1M-1 in addition to the } 500 \text { g moderator limit). } \\
\text { Training on the CHCS was conducted on section } 5 \text { which provided the basis } \\
\text { for HFEF personnel to use the catch tray. }\end{array}$ \\
\hline Oct, 2011 & $\begin{array}{l}\text { HFEF work stoppage due to exposure issue at the HFEF glove wall. (This } \\
\text { postponed the installation of the catch tray until Jan, 2012.) }\end{array}$ \\
\hline Nov 7, 2011 & $\begin{array}{l}\text { Rev } 9 \text { of CHCS was released to address removal of oil and oil bottles at } \\
\text { Window IM. Training was conducted on requirements for removal through } \\
\text { various zones. It was assumed that the through the revision, an analysis } \\
\text { occurred and moderator material in } 1 \mathrm{M} \text { and } 20 \mathrm{M} \text { were exempted. It was } \\
\text { determined that this assumption was never verified. }\end{array}$ \\
\hline Dec. 2011 & $\begin{array}{l}\text { Facility Hazards Review was conducted by the facility to address the oil and } \\
\text { the oil bottles in the cell. Determined that the oil leak was not an issue due to } \\
\text { the oil being collected. }\end{array}$ \\
\hline $\operatorname{Jan} 2012$ & $\begin{array}{l}\text { The collection tray for window } 1 \mathrm{M} \text { was installed. After the catch tray was } \\
\text { installed, the rule that allowed the CSO to exempt moderator in Zones was } \\
\text { removed from the CHCS. }\end{array}$ \\
\hline Feb, 2012 & $\begin{array}{l}\text { The oil is changed out in the window with a different brand. (Per the SME } \\
\text { from Hot Cell Services, changing oil brands can cause an increase in the leak } \\
\text { rate.) }\end{array}$ \\
\hline $\begin{array}{l}\text { Early April } \\
\qquad 2012\end{array}$ & $\begin{array}{l}\text { Radiography work conducted in the elevator shaft, in which material is placed } \\
\text { through the } 4 \mathrm{M} \text { Zone, did not have any observable defects in the film being } \\
\text { developed. }\end{array}$ \\
\hline $\begin{array}{l}\text { Mid-April } \\
\quad 2012\end{array}$ & $\begin{array}{l}\text { Materials \& Fuels Complex (MFC) entered a Safety Stand Down due to } \\
\text { previous events that had occurred within MFC Complex. The Stand Down } \\
\text { lasted and impacted programmatic work until approximately September } 2012 .\end{array}$ \\
\hline
\end{tabular}




\begin{tabular}{|c|ll|}
\hline CAUSAL ANALYSIS OF THE & Identifier: & INL/EXT-12-27982 \\
UNCONTROLLED MODERATOR IN THE & Revision: & 0 \\
Effective Date: & $12 / 19 / 2012$ & Page: 8 of 23 \\
HFEF MAIN CELL & & \\
\hline
\end{tabular}

\begin{tabular}{|c|c|}
\hline Date & Action/Activity \\
\hline May 2012 & $\begin{array}{l}\text { Adjustments to the catch tray system were made. No cleanup of the oil was } \\
\text { conducted at this time due to it being outside the scope of the approved } \\
\text { activities from the Stand Down. Only certain approved min safe activities } \\
\text { were allowed. It took nearly } 6 \text { days to get final authorization to adjust the } \\
\text { catch tray at Window } 1 \mathrm{M} \text { because adjustments / removal of bottles were } \\
\text { considered programmatic work and not min-safe. During this same } \\
\text { timeframe, the Argon purge to the Window } 1 \mathrm{M} \text { was decreased which } \\
\text { decreased the pressure on the window to minimize oil leakage. }\end{array}$ \\
\hline Sept 2012 & Operations resumed at MFC. \\
\hline Sept 17,2012 & $\begin{array}{l}\text { Operators noticed oil was not filling bottles as expected at Window } 1 \mathrm{M} \text {. } \\
\text { NFM directed all operations to stop in the Main Cell, placed the facility into a } \\
\text { safe condition, made notifications, placed the catch tray back into position. }\end{array}$ \\
\hline Sept 27,2012 & $\begin{array}{l}\text { Radiography work resumed and defects were identified after film } \\
\text { development. Inspections of the film revealed defects in the images. } \\
\text { Investigations into what caused the defects were being conducted. }\end{array}$ \\
\hline Nov 1,2012 & $\begin{array}{l}\text { A camera was placed in the NRAD elevator shaft as part of inspections to } \\
\text { determine the source of defects captured on the radiography images. }\end{array}$ \\
\hline Nov 6, 2012 & $\begin{array}{l}\text { Subsequent investigations into the beam defects were identified when a } \\
\text { camera was placed under the false floor of the Main Cell near a window at } \\
\text { the } 4 \mathrm{M} \text { Zone. At this point, oil was found under the false floor beneath the } \\
\text { Zone. The HFEF Nuclear Facility Manager was notified and the HFEF } \\
\text { Criticality Safety Officer was instructed to contact Criticality Safety } \\
\text { Engineering to assist in evaluating the issue. In addition, Nuclear Safety } \\
\text { Engineering was notified to perform a PISA RD. A determination was made } \\
\text { by HFEF Management to characterize the oil. }\end{array}$ \\
\hline Nov 7,2012 & $\begin{array}{l}\text { Investigation into the oil began and puddles of oil were identified well outside } \\
\text { the } 1 \mathrm{M} \text { zone. Operations in the Main Cell were stopped and the process } \\
\text { started to enter the repair mode. Additionally, fissile material transfers were } \\
\text { suspended until minimum safe controls were analyzed and put in-place } \\
\text { through the approved USQ. Notifications were made to the DOE Field } \\
\text { Representative. }\end{array}$ \\
\hline
\end{tabular}




\begin{tabular}{|c|c|c|c|}
\hline $\begin{array}{l}\text { CAUSAL ANALYSIS OF THE } \\
\text { UNCONTROLLED MODERATOR IN THE } \\
\text { HFEF MAIN CELL }\end{array}$ & $\begin{array}{l}\text { Identifier: } \\
\text { Revision: } \\
\text { Effective Date: }\end{array}$ & $\begin{array}{l}\text { INL/EXT-12-27982 } \\
0 \\
12 / 19 / 2012\end{array}$ & Page: 9 of 23 \\
\hline
\end{tabular}

\subsection{Discussion of the Evaluation and Mitigations of the Leaking Window}

The investigation evaluated two different options that were available to MFC management as a result of the leak that led up to the Uncontrolled Moderator in the HFEF Main Cell. The options being:

1. Repair or replace the leaking window or

2. Implement controls to control the leak.

\section{Repair/Replacement of the window:}

From interviews with every facility manager (with the exception of the facility manager who was present when the leak began who at this time is no long working at MFC/BEA and was not available for interviewing), each indicated that a request for funding for repair or replacement was enacted yet never received. The two main reasons why funding was not provided was:

1. At the inception of the leak, the amount of oil leaking was minimal and was deemed that cleaning up the leak was an acceptable method of control versus identifying additional controls to prevent the spread of the oil. Therefore, when the window repair/replacement was prioritized against other equipment repair/replacement issues, the repair/replacement of the window fell below the cut line. Operation personnel noticed ofl on the floor and were not alarmed as they were conditioned to see oil there. After living with it for years, they never truly placed the proper priority on getting the repair complete. Additionally, management's lack of understanding in the change in the leak rate continued to place the window below the line for available funding.

2. Based on funding protocols, funding works on a two year budget request cycle whereby BEA request funding for $\mathrm{FY}+2$ on an annual basis. This is BEA's opportunity to request the funding they believe is needed from DOE. The Idaho Facilities Management (IFM) program is a single congressional appropriation based on a presidential budget request. The presidential budget request is subdivided into subcategories with the two primary ones being nuclear reactor research (ATR, NRAD, TREAT) and non-reactor nuclear research (MFC base ops). BEA has an integrated priority lists (IPL) developed at the subcategory level and owned by the performing organization that supports developing a single IPL or IFM list. This IPL is the vehicle MFC uses to request scope that is beyond historical levels of corrective maintenance. MFC management needs to be able to understand the risks of not funding issues and make a call on where the line is drawn in their request. Historically general guidance for base operations is flat funding escalated because that is the easiest fallback. The IPL has a line item that is entitled "MFC Sustainment", which has been at $\$ 5 \mathrm{M}$ a year. DOE Nuclear Energy (NE) has repeatedly asked about scope specifically associated with these line items and historically, requests for details did not contain the specifics NE-32 requested and therefore $\mathrm{NE}$ was not supportive of the request and did not include the funding in BEA's requests to the Office of Management and Budget (OMB).

MFC management has acknowledged the need for additional rigor in scope development for items on the IPL and has made progress in that area. The major challenge still is the lack of cost estimates to execute the list with any fidelity. MFC now has a decent detailed IPL and recognizes the need to advocate for funding and be able to provide the back up to support the requests. Cost estimates still need to be refined. 


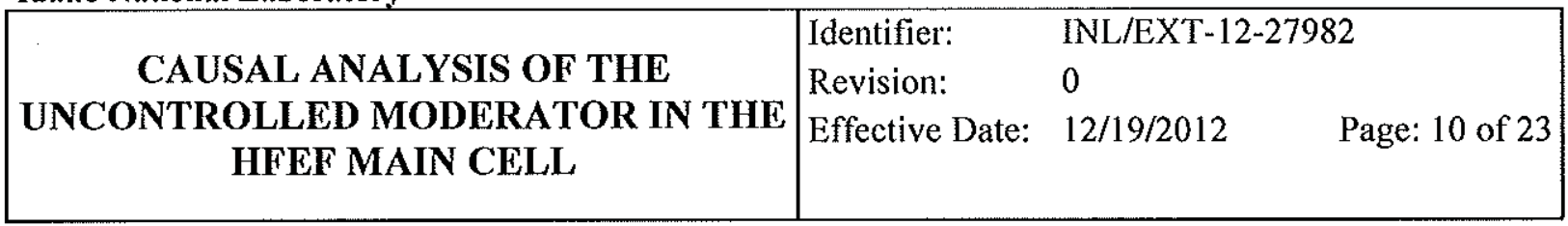

Implement controls to control the leak:

The leak began in the '07-08' timeframe as documented above. (The facility manager at the time the leak began is no long working at MFC/BEA and was not available for interviewing). The replacement manager found out about the leak while performing an area walk-down one day and a facility technician brought it to his attention. The facility manager also brought it to the attention of his upper management. At this time the area covered by the leak was about 3-4 inches in diameter and management of the leak cleanup was easily performed.

In a discussion with a facility technician, it was discussed that the operations personnel would periodically ( 2 to 3 times a week) check for oil on the floor and cleaned up the oil as needed. Additionally, a $\log$ was initiated to track the amount of oil that was added to the window. Later, controls were added to record the amount of oil collected in each bottle ( $4 \mathrm{~L}$ in size) via a facility specific long term order. While tracking of the oil collected was established in 2012 , no administrative tool was established for tracking and trending the mass balance of the oil or verifying the catch tray remained in its proper location to perform its intended function.

PISA

An additional point of interest to the investigation team was the PISA and why this scenario was not previously identified. The identified flashover fire event PISA-RD (MFC-USQ-2012-284) was initiated from the extent of condition review as documented in TEV-1516. At the time of this review, it was believed that all of the oil was being collected and there was no concern expressed that window oil was migrating throughout the main cell. Therefore, based on the belief that all the oil was being collected in bottles, the upgrade HFEF SAR (SAR-405) bounding fire accident in the main cell was deemed a flashover fire event and the current SAR (DSA-003-HFEF) does not describe a flashover event. The bounding fire event in DSA-003 is a pyrophoric event. A PISA-RD compared the dose consequences from the flashover event and pyrophoric event to determine if there was a PISA-RD. The dose consequence for the pyrophoric event was the bounding event and the PISA-RD was determined to be negative.

A positive USQ and PISA have been declared with the loss of moderator control because the loss of control of window oil leads to untracked moderator in some main cell criticality zones that may exceed the criticality safety limits for moderated-limited CHC Zones.

\subsubsection{ISMS Core Functions}

\subsection{Analysis}

The Why Tree Analysis, Behavior Table, and Barrier Analyses were used in this cause analysis. The results of this analysis are also summarized within the context of the ISMS guiding principles.

\section{Core Function 1-Define the Scope of Work (knowing that your system leaked)}

Missions are translated into work, expectations are set, tasks are identified and prioritized, and resources are allocated.

This core function was met.

The leak was identified in 2007. Funding requests were submitted for repair/replacement of the window, however, based on the initial size of the oil leaking on the floor (approximately 3 to 4 inched in 


\begin{tabular}{|c|c|c|c|}
\hline $\begin{array}{l}\text { CAUSAL ANALYSIS OF THE } \\
\text { UNCONTROLLED MODERATOR IN THE } \\
\text { HFEF MAIN CELL }\end{array}$ & $\begin{array}{l}\text { Identifier: } \\
\text { Revision: } \\
\text { Effective Date: }\end{array}$ & $\begin{array}{l}\text { INL/EXT-1 } \\
0 \\
12 / 19 / 2012\end{array}$ & Page: 11 of 23 \\
\hline
\end{tabular}

diameter) and cleanup being relatively easy, funding determinations where placed on higher prioritized issues. However, cleanup activities were performed

Engineering was tasked with developing a catch tray that could divert the leaking material into a container.

\section{Core Function 2 - Analyze the Hazards}

Hazards associated with the work are identified, analyzed, and categorized.

This core function met.

When the leak started, it was recognized as a moderator and has been since. Funding requests were submitted for repair/replacement of the window, however, based on the initial size of the leak (approximately 3 to 4 inched in diameter) and cleanup being relatively easy, funding determinations where placed on higher prioritized issues. However, cleanup activities were performed

Engineering was tasked with developing a catch tray that could divert the leaking material into a container.

\section{Core Function 3 - Develop and Implement Hazard Controls}

Applicable standards and requirements are identified and agreed upon, controls to prevent/mitigate hazards are identified, the safety envelope is established, and controls are implemented.

This core function was not fully met.

While a $\log$ was initiated to track the amount of oil that was added to the window and additional controls were added to record the amount of oil collected in each bottle, hazard controls were not established for tracking and trending the mass balance of the oil or verifying the catch tray was performing its intended function. Compensatory measures were not established at the inception of the leak other than cleaning up the oil which conditioned the facility personnel to accept the oil on the floor and never placing a priority on getting the issue repaired. Additionally, there is not a preventative maintenance (PM) program in place for shielding windows.

\section{Core Function 4 - Perform Work within Controls}

Readiness is confirmed and work is performed safely.

LWP-13845, "Cause Analysis, Corrective Action, and Investigation Report Process" states that once one core finction fails, there is no need to contimue the Core Functions analysis.

\section{Core Function 5 - Provide Feedback and Continuous Improvement}

Feedback information on the adequacy of controls is gathered, opportunities for improving the definition and plamning of work are identified and implemented, line and independent oversight is conducted, and, if necessary, regulatory enforcement actions occur.

LWP-13845, "Cause Analysis, Corrective Action, and Imvestigation Report Process" states that once one core function fails, there is no need to continue the Core Functions analysis. 


\begin{tabular}{|c|c|c|c|}
\hline $\begin{array}{l}\text { CAUSAL ANALYSIS OF THE } \\
\text { UNCONTROLLED MODERATOR IN THE } \\
\text { HFEF MAIN CELL }\end{array}$ & $\begin{array}{l}\text { Identifier: } \\
\text { Revision: } \\
\text { Effective Date: }\end{array}$ & $\begin{array}{l}\text { INL/EXT- } 1 \\
0 \\
12 / 19 / 2012\end{array}$ & Page: 12 of 23 \\
\hline
\end{tabular}

\section{CONCLUSIONS}

The causes to this event are described as Causal Factors listed below. Causal Factors are the root causes that if corrected would prevent this event from recurring. Cause codes listed are per Occurrence Reporting Causal Analysis Guide (DOE G 231.1-2).

\subsection{Causal Factors}

A2B6C04, End of life failure (The failure resulted from equipment or material having reached the end of its expected/normal service life. The failure was a result of the normal aging process for this component.) - The window is leaking due to the failure of the seal/gasket. The design life for these seal is 10 years. The PM program on the windows should be strengthened to perform tracking and inspections of the windows to identify degradation.

$\mathrm{A} 3 \mathrm{~B} 2 \mathrm{C} 04$, Previous success in use of rule reinforced continued use of rule. (If a rule for behavior has been used successfully in the past, there is an overwhelming tendency to apply the rule again, even though circumstances no longer warrant the use of the rule.) - Those who noticed oil on the floor were not alarmed as they were conditioned to see oil there after living with it for years and never truly placing priority on getting the repair complete. Between the period of 2007-2012, the CHCS allowed the CSO to declare the oil as not moderator. After the rule change in March 2012 to the CHCS, operations personnel who noticed the oil on the floor were not alarmed as they were conditioned to the previous rule where the CSO declared the oil as not moderator.

A4B1C04, Management follow-up or monitoring of activities did not identify problems. (Management's methods for monitoring the success of initiatives were ineffective in identifying shortcomings in the implementation.) Management failed to provide the proper oversight to ensure the catch tray was in position and performing as designed.

A4B 1C09, Corrective actions for previously identified problem or event was not adequate to prevent recurrence (Management failed to take meaningful corrective action for consequential or nonconsequential events.)-A requirement wasn't established to track the mass balance of the oil, and there wasn't a requirement to verify the tray was performing its intended function.

\subsection{Corrective Actions}

The following corrective actions have been developed to address the root causes (causal factors) that contributed to this event:

1. Establish compensatory measures for ensuring the leak detection apparatus is properly oriented. (A3B2C04/ A4B1C04/ A4B1C09)

Due date: $01 / 31 / 13$

Action Assigned to: John Krause

Objective Evidence: Copy of the log documenting the inspection 


\begin{tabular}{|c|c|c|c|}
\hline $\begin{array}{l}\text { CAUSAL ANALYSIS OF THE } \\
\text { UNCONTROLLED MODERATOR IN THE } \\
\text { HFEF MAIN CELL }\end{array}$ & $\begin{array}{l}\text { Identifier: } \\
\text { Revision: } \\
\text { Effective Date: }\end{array}$ & $\begin{array}{l}\text { INL/EXT-1 } \\
0 \\
12 / 19 / 2012\end{array}$ & Page: 13 of 23 \\
\hline
\end{tabular}

2. Establish a mass balance process for the oil collection system and provide documentation method on mass balance tracking form. (A4B1C09)

Due date: $01 / 31 / 13$

Action Assigned to: John Krause

Objective Evidence: Copy of updated forms

3. Evaluate the $1 \mathrm{M}$ window repair options and document in TEV-1541. (A2B6C04)

Due date: $02 / 14 / 13$

Action Assigned to: Ron Johansen

Objective Evidence: Copy of The approved TEV-1541.

4. Review the existing PMs for the oil-filled windows and modify as necessary. (A2B6C04)

Due date: 03/06/13

Action Assigned to: Ron Johansen

Objective Evidence: Copy of an e-mail and/or the PMJ's .

5. Develop an INL Lessons Leamed on the event of the oil leaking from the $1 \mathrm{M}$ window.

Due date: $02 / 21 / 13$

Action Assigned to: Sean Cunningham

Objective Evidence: Copy of Lessons Learned from the INL Lesson Learned database

6. Perform an MFC based extent of conditions on oil-filled windows for leaks and the effect, if any, of the leak based on requirements listed in the Criticality Hazards Control Statement.

Due date: $03 / 14 / 13$

Action Assigned to: Sean Cumningham

Objective Evidence: A documented extent of conditions

\section{Immediate Actions Taken}

1. Operations in the HFEF Main Cell were stopped and all fissile material movements were suspended.

2. Established a cleanup/removal methodology for the spilled oil.

3. Issued long term order (LTO) HFEF-LT-32 to ensure a visual inspection of the $1 \mathrm{M}$ window catch tray for proper alignment and trained Operations personnel on the LTO requirements

4. Completed the PISA RD and PISA to evaluate loss of moderator control and implemented controls

5. Engaged Hot Cell Services for $1 \mathrm{M}$ window repairs 


\begin{tabular}{|c|c|c|c|}
\hline $\begin{array}{c}\text { CAUSAL ANALYSIS OF THE } \\
\text { UNCONTROLLED MODERATOR IN THE } \\
\text { HFEF MAIN CELL }\end{array}$ & $\begin{array}{l}\text { Identifier: } \\
\text { Revision: } \\
\text { Effective Date: }\end{array}$ & $\begin{array}{l}\text { INL/EXT- } 1 \\
0 \\
12 / 19 / 2012\end{array}$ & Page: 14 of 23 \\
\hline
\end{tabular}

\section{Path Forward for the window:}

The following path forward is being implemented/evaluated:

As a temporary control measure, the argon purge pressure will be lowered on the window expansion tank oil. Reduction of the purge pressure is anticipated to reduce the leak rate by a factor of 3 to 4 . This control measure is temporary until the oil leak can be corrected and will be implemented via Engineering Job Number EJ-1215, "Window 1M Expansion Tank Purge Modification".

- Design a replacement A-slab and gasket system. The replacement A-slab and gasket system will allow collection of the oil between the A-slab and tank unit until the oil leak is corrected.

- The window tank unit must be replaced or refurbished to correct the oil leak. Refurbishment of the tank unit can take 3-4 months and can be extended if glass is advertently damaged and must be replaced. A replacement tank unit is expected to be fabricated to reduce facility down time during the window tank replacement. The existing tank unit will be refurbished after removal to allow installation at another location for future repairs.

The above actions are preliminary and will be further developed and documented in TEV-1541. 


\begin{tabular}{|c|c|c|c|}
\hline $\begin{array}{l}\text { CAUSAL ANALYSIS OF THE } \\
\text { UNCONTROLLED MODERATOR IN THE }\end{array}$ & $\begin{array}{l}\text { Identifier: } \\
\text { Revision: } \\
\text { Effective Date: }\end{array}$ & $\begin{array}{l}\text { INL/EXT-1 } \\
0 \\
12 / 19 / 2012\end{array}$ & $\begin{array}{l}82 \\
\text { Page: } 15 \text { of } 23\end{array}$ \\
\hline
\end{tabular}

\section{APPENDIX A}

\section{WHY TREE}

- There was an oil leak and loss of control of moderator material in the HFEF main cell.

- Why was there an oil leak?

- The window gaskets are approximately 40 years old which are 30 years past design life and leaking allowing the moderator to enter the cell. (A2B6C04, End of life failure)

- Why were the gaskets in the facility 30 years past their design life?

- Funding prioritization and the leak rate change was not well communication to management deemed the risk of the leaking window less important than other equipment problems.

- Why was the risk of the leaking window less important than other equipment problems?

- The initial amount of oil leaking was insignificant as a moderator in the location it was found (1M window) and moderator controls were addressed in the CHCS. It was also believed that the tray was catching all of the oil.

- Why is the amount of oil leaking a problem now?

- The amount of oil leaking now is of an amount that it must be controlled to prevent the spread of the oil (moderator) outside the $1 \mathrm{M}$ window area. From interviews, the initial leak was only a few inches in diameter. The leak rate has increased due to the change in oil type in Feb, and has overcome the previously installed corrective actions.

- Why wasn't it controlled prior to the time of the event where the loss of control caused a problem?

The leak was not controlled at the source through either engineering controls or administrative practices due to poor risk analysis, and setting priority to install the catch tray earlier in the leak time frame. A requirement wasn't established to track the mass balance of the oil, and there wasn't a requirement to verify the tray was performing its intended function. Those who noticed oil on the floor were not alarmed as they were conditioned to see oil there after living with if for years and never truly placing priority on getting the repair complete. Management failed to provide oversight to ensure the catch tray was in position and performing as designed.

$\mathrm{A} 3 \mathrm{~B} 2 \mathrm{C} 04$, Previous success in use of rule reinforced continued use of rule.

A4B1C04, Management follow-up or monitoring of activities did not identify problems. .

A4B1C09, Corrective actions for previously identified problem or event was not adequate to prevent recurrence. 


\begin{tabular}{|c|c|c|c|}
\hline $\begin{array}{c}\text { CAUSAL ANALYSIS OF THE } \\
\text { UNCONTROLLED MODERATOR IN THE } \\
\text { HFEF MAIN CELL }\end{array}$ & $\begin{array}{l}\text { Identifier: } \\
\text { Revision: } \\
\text { Effective Date: }\end{array}$ & $\begin{array}{l}\text { INL/EXT-1 } \\
0 \\
12 / 19 / 2012\end{array}$ & Page: 16 of 23 \\
\hline
\end{tabular}

INTENTIONALLY BLANK

Appendix A 